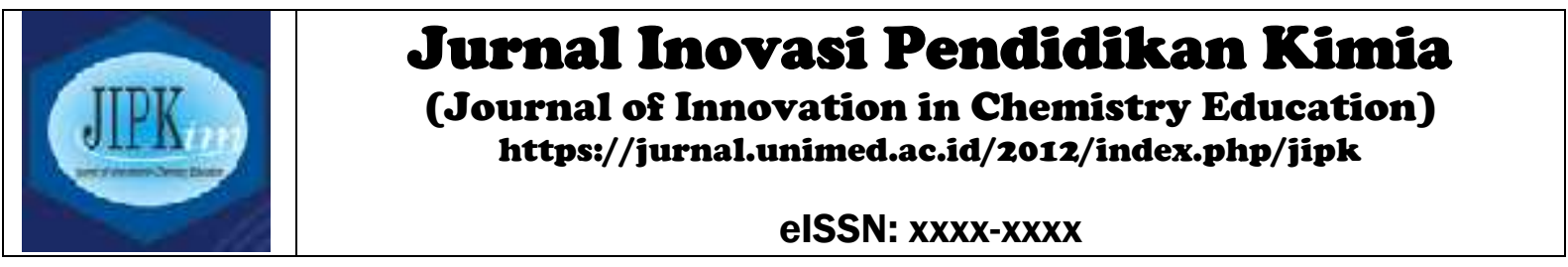

\title{
Perbedaan Hasil Belajar Siswa Menggunakan Model Kooperatif Tipe MM dan TGT dengan bantuan Powerpoint
}

\author{
Ayu Puspita Sari ${ }^{\mathrm{a}, *}$, dan Lisnawaty Simatupang ${ }^{\text {a }}$ \\ ${ }^{a}$ Program Studi Pendidikan Kimia, Universitas Negeri Medan, Medan \\ *Alamat Korespondensi: zaharahalim12@gmail.com
}

\begin{abstract}
Abstrak:
Penelitian ini bertujuan untuk mengetahui apakah ada perbedaan hasil belajar siswa menggunakan model kooperatif tipe Make a Match (MM) dan Teams Games Tournament(TGT) dengan bantuan PowerPoint pada pokok bahasan koloid. Sampel yang digunakan sebanyak 2 kelas reguler dengan teknik random sampling (acak) dan masing-masing kelas terdiri atas 40 siswa. Pada kelas eksperimen I diberi pengajaran dengan model kooperatif tipe MM dengan bantuan powerpoint dan pada kelas eksperimen II diberikan pengajaran dengan model TGT dengan bantuan powerpoint. Hasil pengolahan data menunjukkan siswa pada kelas MM memiliki rata - rata nilai pre-tes 51,44 $\pm 17,85$ dan post-tes $87,62 \pm 6,25$ dengan rata - rata gain sebesar $73,53 \%$. Sedangkan siswa pada kelas TGT memiliki rata - rata nilai pre-tes 45,25+14,24 dan post-tes83,94+5,58 dengan rata - rata gain sebesar $69,46 \%$. Uji hipotesis dilakukan dengan menggunakan uji t dua pihak dari data hasil belajar dan diperoleh $\mathrm{t}_{\text {hitung }}=2,80$ sedangkan $\mathrm{t}_{\text {tabel }}=1,994$ untuk $\alpha=0,05$ dan $\mathrm{db}=78$, sehingga $t_{\text {hitung }}>t_{\text {tabel. }}$ Maka Ha diterima yakni ada perbedaan hasil belajar siswa menggunakan model kooperatif tipe MM dengan bantuan powerpoint dengan model TGTdengan bantuan powerpoint yaitu sebesar $4,07 \%$. Berdasarkan perbandingan peningkatan hasil belajar siswa diperoleh bahwa hasil belajar yang tertinggi yaitu dengan pembelajaran menggunakan model MM.
\end{abstract}

Kata kunci:

Make a match, Teams games tournament, powerpoint, hasil belajar, koloid

\section{PENDAHULUAN}

Pendidikan merupakan sebuah proses dinamis dan berkelanjutan yang bertugas memenuhi kebutuhan siswa dan guru sesuai dengan minat mereka masing-masing. Pendidikan memiliki tanggung jawab untuk meningkatkan minat siswa, memperluas dan mengembangkan keilmuan mereka, dan membantu mereka agar mampu menjawab tantangan dan gagasan baru dimasa mendatang. Pendidikan harus mendesain pembelajaran yang responsif dan berpusat pada siswa agar minat dan aktivitas sosial mereka terus meningkat (Fadliana, 2013).

Menurut Syadiyah (2013) mengatakan bahwa masalah pokok yang dihadapi dunia pendidikan di Indonesia saat ini adalah masalah yang berhubungan dengan mutu atau kualitas pendidikan yang masih rendah.
Rendahnya kualitas pendidikan ini terlihat dari rendahnya kualitas guru, sarana belajar dan rendahnya capaian daya serap siswa terhadap materi pelajaran yang disebabkan oleh banyak faktor, salah satunya adalah rendahnya kualitas proses pembelajaran di sekolah.

Guru mempunyai peranan yang menentukan di dalam mengarahkan proses belajar, tetapi berperan pula di dalam merancang dan mengontrol proses belajar. Apabila guru dapat melaksanakannya secara efesien dan efektif di dalam merekayasa pengajaran di sekolah, maka dengan sendirinya akan berlangsung proses belajar yang efesien sehingga pada akhirnya terwujudlah pola tingkah laku yang diharapkan. Dalam pembelajaran, anak hendaknya menjadi subjek (pelaku) bukan yang dikenai perlakuan (objek). Dengan 
menjadi subjek seluruh tubuh anak terlibat, juga emosi, dan pemikiran serta daya khayalnya.

Menurut Winarti dalam Dash (2014) mengatakan bahwa kenyataan yang sering terdapat disekolah adalah kecenderungan guru yang memberikan pembelajaran kimia dengan metode ceramah, mengajak siswa untuk membaca bahan ajar, dan menghapal konsep-konsep kimia. Kondisi pembelajaran kimia seperti ini akan menyebabkan pelajaran kimia menjadi tidak menarik, tidak disenangin dan dengan demikian hasil belajar siswa menjadi rendah.

Menurut Ajick (2009) mengatakan, pelajaran Kimia adalah mata pelajaran wajib Sekolah Menengah Atas (SMA) Progam IPA. Dalam mempelajari ilmu Kimia siswa menemui kesulitan yang dapat bersumber pada : (1) kesulitan dalam memahami istilah, kesulitan ini timbul karena kebanyakan siswa hanya hafal akan istilah dan tidak memahami dengan benar maksud dari istilah yang sering digunakan dalam pengajaran kimia; (2) kesulitan dengan angka, sering dijumpai siswa yang kurang memahami rumusan perhitungan kimia, hal ini disebabkan karena siswa tidak mengetahui dasar-dasar matematika dengan baik; dan (3) kesulitan dalam memahami konsep kimia. Kebanyakan konsep-konsep dalam ilmu kimia merupakan konsep atau materi yang abstrak dan kompleks sehingga untuk mengatasi hal tersebut, konsep perlu ditunjukkan dalam bentuk yang lebih konkret, misalnya dengan percobaan atau media tertentu.

Mata pelajaran Kimia merupakan mata pelajaran IPA yang banyak menggunakan konsep dari yang sederhana sampai yang lebih kompleks sehingga diperlukan pemahaman yang benar terhadap konsep dasar. Banyak diantara siswa yang sering kali memaknai konsep yang kompleks menjadi konsep yang membingungkan dan menyebabkan siswa kurang tertarik terhadap materi pelajaran kimia.

Berdasarkan fakta di lapangan, SMA Negeri 1 Binjai masih menggunakan model pembelajaran teacher centered artinya proses belajar masih terpusat pada guru, sehingga siswa tidak ikut terlibat secara aktif dalam proses belajar mengajar tersebut. Hal ini dikarenakan sifat dari metode pembelajaran tersebut adalah satu arah yaitu dari guru ke siswa yang menyebabkan siswa kurang aktif dalam belajar. Oleh karena itu, diperlukan model pembelajaran yang dapat melibatkan siswa aktif untuk berpikir dan mengembangkan pengetahuan, memberikan dukungan serta kesempatan kepada siswa untuk mengembangkan ide-idenya. Selain penggunaan model pembelajaran, media sangat diperlukan untuk mempermudah pemahaman siswa tentang materi yang disampaikan. Media juga meningkatkan minat siswa dalam proses pembelajaran. Dengan bantuan media, pembelajaran akan menjadi lebih mudah dan hasil akan menjadi maksimal.

Make a match atau mencari pasangan merupakan salah satu alternatif yang diterapkan kepada siswa. Penerapan model ini dimulai dari teknik yaitu siswa diminta untuk mencari pasangan kartu yang merupakan jawaban/soal sebelum batas waktunya, siswa yang dapat mencocokkan kartunya diberi poin, sehingga pembelajaran akan lebih menyenangkan dan membuat siswa aktif dalam belajar (Prihantoro, 2014).

Teams games tournament adalah salah satu tipe pembelajaran kooperatif yang menempatkan siswa dalam kelompokkelompok belajar yang beranggotakan 5 sampai 6 orang siswa yang memiliki kemampuan, jenis kelamin dan suku kata atau ras yang berbeda. Guru menyajikan materi, dan siswa bekerja dalam kelompok mereka masing-masing (Rusman, 2011).

Kedua model pembelajaran ini mampu meningkatkan hasil belajar siswa dalam pembelajaran. Siswa dituntut untuk berpikiraktif, mengembangkan pengetahuan, memberikan dukungan serta kesempatan kepada siswa untuk mengembangkan ideidenya, tetapi penerapan model pembelajaran saja belum cukup untuk memaksimalkan hasil belajar kimia siswa, karena itu diperlukan media dalam menyampaikan informasi pelajaran agar pembelajaran kimia tidak bersifat khayalan. 
Salah satu media yang dapat digunakan adalah powerpoint. Melalui powerpoint, kegiatan pembelajaran dapat lebih intraktif dan dapat meberikan pengalaman visual kepada siswa dalam rangka memberi motivasi belajar, memperjelas, dan mempermudah konsep yang kompleks serta abstrak menjadi lebih sederhana, konkrit, juga mudah dipahami.

\section{METODE}

Penelitian ini dilaksanakan di SMA Negeri 1 Binjai, kurikulum yang digunakan adalah KTSP.Populasi penelitian seluruh siswa kelas XI IPA SMA N 1 Binjai yang terdiri dari 6 kelas IPA, 5 kelas adalah kelas regular dan 1 kelas adalah kelas unggulan.Jumlah siswa setiap kelasnya ratarata berjumlah 40 orang. Sampel dalam penelitian ini terdiri dari dua kelas yang diambil secara acak (random sampling) dari lima kelas reguler. Kelas pertama yaitu kelas XI IPA2 dijadikan sebagai kelas eksperimen I yang menggunakan model kooperatif tipe make a match dengan bantuan Powerpoint dan kelas kedua yaitu kelas XI IPA3 dijadikan sebagai kelas eksperimen II yang menggunakan model teams games tournament dengan bantuan Powerpoint.

Dalam penelitian ini yang dijadikan variabel bebas yaitu model Make a Match dan Teams Games Tournament dengan media Powerpoint, variabel terikat yaitu peningkatan hasil belajar siswa. Instrumen yang digunakan dalam pengumpulan data pada penelitian ini adalah tes objektif dalam bentuk pilihan berganda. Sebelum dilakukan penelitian, tes objektif yang telah disusun sesuai indikator terlebih dahulu divalidkan oleh validator ahli kemudian dilakukan uji instrumen berupa uji validitas item, reliabilitas tes, tingkat kesukaran, dan daya beda tes.

Rancangan penelitian yang digunakan dalam penelitian ini adalah rancangan eksperimen sungguhan dengan menggunakan bentuk pre-tes-post-tes control group design. Dalam rancangan ini, penelitian dilakukan di dua kelas, dimana kedua kelas diberi perlakuan yang berbeda yaitu, kelas eksperimen I (model make a match dengan media powerpoint) dan kelas eksperimen II (model teams games tournament denganmedia powerpoint).

Langkah-langkah penelitian yang akan dilakukan dalam rancangan penelitian pretes-post-tes control group design adalah sebagai berikut:

1. Pemilihan kelas sampel dari populasi yang ada dengan cara acak.

2. Melakukan pendataan siswa-siswi di kelas eksperimen I dan kelas eksperimen II.

3. Melaksanakan pre-tes untuk mengukur prestasi belajar $\left(\mathrm{T}_{1}\right)$ sebelum perlakuan.

4. Menetapkan sampel siswa yang relatif homogen

5. Memberikan perlakuan yang berbeda di kelas eksperimen I dan kelas eksperimen II selama beberapa waktu tertentu.

6. Mempertahankan kondisi pada kedua kelas selama proses penelitian

7. Melakukan post-tes

8. Mentabulasi data skor atau nilai pretes dan post-tes setiap siswa, kemudian menghitung selisih nilai hasil belajar yang diperoleh di kelas eksperimen I maupun kelas eksperimen II sebelum dan sesudah perlakuan (post-tes - pre-tes)

9. Melakukan uji persyaratan analisis statistik terutama uji normalitas dan uji homogenitas data

10. Menerapkan uji statistik yang cocok (uji dua pihak) untuk menguji apakah ada perbedaan hasil belajar di kelas eksperimen I dengan di kelas eksperimen II.

11. Menarik kesimpulan penelitian.

Teknik analisis data yang dilakukan yaitu berupa perhitungan uji normalitas, uji homogenitas, dan uji hipotesis.Uji normalitas yang digunakan pada penelitian ini mengunakan uji chi-kuadrat.Setelah menghitung uji normalitas dilanjutkan dengan uji homogenitas guna untuk 
mengetahui data-data tersebut homogen atau tidak.Selanjutnya dilakukan uji hipotesis, dimana uji hipotesis yang digunakan adalah uji t dua pihak.

\section{HASIL DAN PEMBAHASAN}

Dalam penelitian ini, hasil belajar yang digunakan atau dianalisis adalah berupa gain ternormalisasi (peningkatan hasil belajar).Sebelum kedua sampel diberikan perlakuan yang berbeda terlebih dahulu diberikan tes awal yakni pre-tes yang bertujuan untuk mengetahui kemampuan awal siswa, distribusi kenormalan siswa, dan untuk membagi siswa ke dalam kelompok kecil yang beranggotakan enam orang dengan kemampuan yang berbeda-beda. Sehingga dalam pelaksanaan proses pembelajaran akan berlangsung secara sharing yaitusiswa yang lebih pintar dapat berbagi ilmu yang dipahaminya dengan siswa yang kurang pintar. Pelaksanaan penelitian ini dilakukan sebanyak tiga kali pertemuan dan diakhri dengan satu kali pertemuan untuk pemberian evaluasi hasil belajar yaitu posttes. Selanjutnya dilakukan pembelajaran yang berbeda yaitu kelas eksperimen I penerapan model Make a Match dengan media Powerpoint dan kelas eksperimen II yaitu model Teams GamesTournament dengan media PowerPoint.

Berdasarkan hasil penelitian dan setelah dilakukan perhitungan rata-rata hasil belajar maka diperoleh nilai rata-rata pre-test dan post-tes untuk kelas eksperimen I (model Make a Match dengan media PowerPoint) sebesar 51,44, dan 87,62. Sedangkan nilai rata-rata pre-tes dan post-tes untuk kelas eksperimen II (model Teams Games Tournament dengan media PowerPoint) sebesar 45,25 dan 83,94.

Perbedaan hasil perolehan rata-rata nilai pre-tet dan post-tes kelas eksperimen I dan kelas eksperimen II dapat digambarkan melalui grafik hasil belajar siswa di bawah ini.Hasil perhitungan persentase peningkatan hasil belajar dapat langsung dicari dari ratarata nilai gain seluruh siswa untuk masingmasing kelas dapat dilihat pada Tabel
1.Berdasarkan tabel 1.maka dapat digambarkan diagram rata-rata nilai gain kelas eksperimen I dan eksperimen II pada Gambar 2.

\section{Hasil Belajar Siswa}

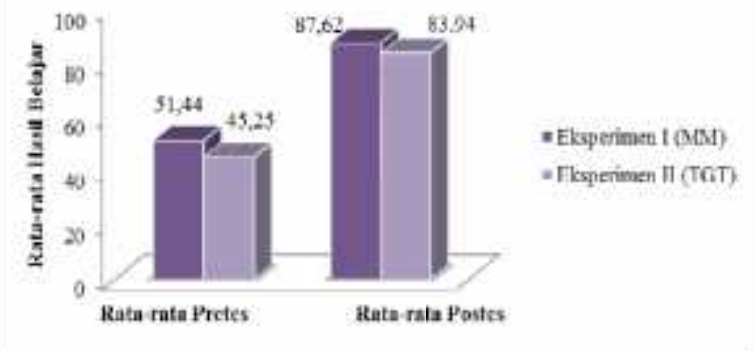

Gambar 1. Diagram nilai rata-rata hasil belajar siswa

Pada pelaksanaannya, pembelajaran yang menggunakan model make a match (membuat pasangan) merupakan salah satu jenis dari model dalam pembelajaran kooperatif. Salah satu keunggulan teknik ini adalah siswa mencari pasangan kartu dalam belajar mengenai suatu konsep atau topik, dalam suasana yang menyenangkan. Model pembelajaran make a match baik digunakan manakala guru menginginkan kreativitas berfikir siswa, sebab melalui pembelajaran seperti ini siswa diharapkan mampu untuk mencocokkan pertanyaan dengan jawaban yang ada di dalam kartu (Ngalimun, 2014).

Kelebihan model pembelajaran koopeartif tipe make a match adalah: (1) siswa terlibat langsung dalam menjawab soal yang disampaikan kepadanya melalui kartu, (2) meningkatkan kreativitas belajar siswa, (3) menghindari kejenuhan siswa dalam mengikuti proses belajar mengajar, (4) dapat menumbuhkan kreativitas berfikir siswa, sebab melalui pencocokan pertanyaan dan jawaban akan tumbuh tersendirinya, dan (5) pembelajaran lebih menyenangkan karena melibatkan media pembelajaran yang digunakan guru. seiring dengan adanya kelebihan dari model make a match, terdapat juga kelemahan dari model make a match itu sendiri yaitu: (1) sulit bagi guru mempersiapkan kartu-kartu yang baik dan 
bagus; (2) sulit mengatur ritme atau jalannya proses pembelajaran dan (3) sulit untuk mengkonsentrasikan anak (Istarani, 2012).Sejalan dengan hal itu maka solusi yang ditawarkan untuk meminimalisir kelemahan dari model make a match tersebut yaitu: (1) seorang guru harus kreatif dalam membuat kartu-kartu games dalam games tersebut, agar para siswa menjadi tertarik dalam mengikuti proses belajar mengajar; (2) seorang guru harus mampu mengendalikan suasana kelas yang gaduh saat games dalam pembelajaran itu berlangsung; (2) guru harus mengendalikan dan harus mampu menstabilkan konsentrasi para peserta didik saat games tersebut berlangsung, dengan tujuan agar apa yang diterima oleh para peserta didik tetap tertanam dalam ingatan mereka.

Model pembelajaran kooperatif teams games tournament adalah salah satu tipe pembelajaran kooperatif yang menempatkan siswa dalam kelompok-kelompok belajar yang beranggotakan 5 sampai 6 orang siswa yang memiliki kemampuan, jenis kelamin dan suku atau ras yang berbeda. Guru menyajikan materi, dan siswa bekerja dalam kelompok mereka masing-masing. Pembelajaran kooperatif tipe teams games tournament terdiri dari lima langkah tahapan, yaitu: tahapan penyajian kelas (class precentation), belajar dalam kelompok (teams), permainan (games), pertandingan (tournament), dan penghargaan kelompok (team recognition), dan model pembelajaran kooperatif tipe TGT ini memiliki ciri-ciri sebagai berikut: (a) siswa bekerja dalam kelompok-kelompok kecil, (b) games tournament dan (c) penghargaan kelompok (Rusman, 2011).

Kelebihan dari model kooperatif tipe teams games tournament: (1) pembelajaran akan lebih menarik karena menggunakan kartu; (2) belajar lebih aktraktif karena dilakukan dalam bentuk permaianan yang mengarah pada suatu permainan; (3) dapat memajukan kerjasama siswa dalam proses belajar mengajar; (4) dapat mengembangkan persaingan yang sehat dalam proses belajar mengajar. Sedangkan untuk kelemahan model pembelajaran teams games tournament itu sendiri yaitu: (1) menggunakan waktu yang cukup lama; (2) harus dilakukan secara berkesinambungan; (3) materi kurang tertanam baik didalam kepala siswa untk dihafal atau diingat kembali (Istarani, 2012).

Sejalan dengan hal itu maka solusi yang ditawarkan untuk meminimalisir kelemahan dari model teams games tournamet tersebut yaitu: (1) seorang guru harus mampu mamanagemen waktu dalam proses pembelajaran agar materi yang disampaikan sesuai dengan waktunya; (2) guru harus mampu membuat para peserta didik tetap tertarik akan adanya pembelajaran dengan model yang ditawarkan sehingga tidak ada kebosan para peserta didik dalam menerima pelajaran yang disampaikan dan pemebelajaran yang disampaikan juga harus berkesinambungan di ajarkan agar materi tetap tertanam dalam ingatan para peserta didik dam tidak akan terjadi kekeliruan dalam menerima mater yang diajarkan; (3) guru harus mampu menyampaikan isi materi pelajaran dengan baik dan benar agar isi materi yang diterima oleh para peserta didik tidak salah konsep dan tetap tertanam dalam ingatannya.

Secara keseluruhan, kedua model pembelajaran tersebut menyajikan materi yang sama, yaitu koloid. Perbedaanya terletak pada konsep awal yang diberikan (langkah-langkah pembelajaran) yang diberikan dan kegiatan pembelajarannya. Pembelajaran dengan model make $a$ matchmenuntut siswa mencari pasangan dalam belajar mengenai suatu konsep atau topik, dalam suasana yang menyenangkan dan pada model make a match ini, pembelajaran yang disajikanpun akan tidak menjadi menoton dan membosankan namun dengan adanya model make a match yang diterapkan ini membuat antusiasme peserta didik dalam belajar menemukan suatu konsep atau topik dikategorikan baik. Hal ini dapat dilihat dari dinamisasi kekompakkan para peserta didik, pertukaran ide (diskusi) dalam mencocokkan suatu kartu soal dan kartu jawaban (Rusman, 2011). 
Tabel 1.Persen peningkatan hasil belajar

\begin{tabular}{clclcc}
\hline \multicolumn{1}{c}{ Kelas } & \multicolumn{1}{c}{ Kriteria } & & Ket: & G & Keterangan \\
\hline \multirow{2}{*}{ Eksperimen I (MM) } & G $<0,3=$ Rendah & $\Sigma \mathrm{g}$ & $=29,41$ & \multirow{2}{*}{$73,53 \%$} & \multirow{2}{*}{ Tinggi } \\
& $0,3<\mathrm{G}>0,7=$ Sedang & $\Sigma \mathrm{g}$ & $=0,7353$ & & \\
Eksperimen II (TGT) & $\mathrm{G}>0,7=$ Tinggi & $\Sigma \mathrm{g}=27,78$ & \multirow{2}{*}{$69,46 \%$} & \multirow{2}{*}{ Sedang } \\
& & $\Sigma \mathrm{g}$ & $=0,6946$ & & \\
\hline
\end{tabular}

Tabel 2.Uji normalitas data hasil belajar siswa

\begin{tabular}{cccccc}
\hline \multicolumn{1}{c}{ Kelas } & $\begin{array}{c}\text { Sumber } \\
\text { Data }\end{array}$ & $\mathbf{X}_{\text {Hitung }}^{2}$ & $\mathbf{X}_{\text {Tabel }}^{\mathbf{2}}$ & $\boldsymbol{\alpha}$ & Keterangan \\
\hline \multirow{2}{*}{ Eksperimen I (MM) } & Pre-tes & 5,76 & 11,07 & 0,05 & Distribusi Normal \\
& Post-tes & 9,41 & 11,07 & 0,05 & Distribusi Normal \\
Eksperimen II (TGT) & Pre-tes & 6,21 & 11,07 & 0,05 & Distribusi Normal \\
& Post-tes & 9,07 & 11,07 & 0,05 & Distribusi Normal \\
\hline
\end{tabular}

Tabel 3.Uji homogenitas data hasil belajar siswa

\begin{tabular}{cccccc}
\hline Sumber Data & Kelas & $\mathbf{S}^{2}$ & $\mathbf{F}_{\text {hitung }}$ & $\mathbf{F}_{\text {tabel }}$ & Keterangan \\
\hline \multirow{2}{*}{ Pre-test } & Eksperimen I (MM) & 318,91 & 1,57 & 1,705 & \multirow{2}{*}{ Homogen } \\
& Eksperimen II (TGT) & 202,77 & & & \\
Post-tes & Eksperimen I (MM) & 39,14 & 1,25 & 1,705 & \multirow{2}{*}{ Homogen } \\
\hline
\end{tabular}

Tabel 4.Uji hipotesisdatahasil belajar siswa

\begin{tabular}{|c|c|c|c|c|}
\hline \multicolumn{2}{|c|}{ Data Kelas } & \multirow[b]{2}{*}{$\mathbf{t}_{\text {hitung }}$} & \multirow[b]{2}{*}{$\mathbf{t}_{\text {tabel }}$} & \multirow[b]{2}{*}{ Keterangan } \\
\hline Eksperimen 1 & Eksperimen 2 & & & \\
\hline $\begin{array}{l}\bar{X}=87,62 \\
S D=6,25 \\
S^{2}=39,14\end{array}$ & $\begin{array}{l}\bar{X}=83,94 \\
\mathrm{SD}=5,58 \\
\mathrm{~S}^{2}=31,19\end{array}$ & 2,80 & 1,994 & Ha diterima, Ho ditolak \\
\hline
\end{tabular}

Pada proses pembelajaran teams games tournament lebih menempatkan siswa dalam kelompok-kelompok belajar yang beranggotakan 5 sampai 6 orang siswa yang memiliki kemampuan, jenis kelamin dan suku atau ras yang berbeda, dimana guru menyajikan materi, dan siswa bekerja dalam kelompok mereka masing-masing, dan pemberian LKS dalam model teams games tournament ini bertujuan untuk menambah dan mengasah pengetahuan para peserta didik mengenai materi yang telah diberikan. Hal ini tentunya akan berpengaruh terhadap aktivitas dan kedalaman pengetahuan siswa karena pengetahuan siswa terbatas pada apa yang diketahui guru. Dengan adanya model pembelajaran teams games tournament ini diharapkan siswa dapat mengembangkan keterampilan berfikir dan menjawab dalam komunikasi antara satu dengan yang lain, serta bekerja saling membantu dalam kelompok kecil dalam suatu tournament (Rusman, 2011).

Hasil perhitungan untuk uji normalitas untuk datapre-tes, post-tes dan data gainkedua kelas, kelas eksperimen I dan eksperimen II dengan menggunakan uji ChiKuadrat pada taraf nyata $\alpha=0,05$ dengan kriteria Chi Kuadrat $\left(\chi^{2}\right)_{\text {hitung }}<\left(\chi^{2}\right)_{\text {tabel }}$ maka dinyatakan data tersebut normal dapat dilihat pada Tabel 2.Hasil perhitungan untuk uji homogenitas untuk data gain kedua kelas sampel dengan membandingkan $F_{\text {hitung }}$ dan $F_{\text {tabel }}$ dikatakan homogen apabila harga $F_{\text {hitung }}<F_{\text {tabel }}$ pada taraf signifikasi $\alpha=0,05$ dapat dilihat pada Tabel 3. Setelah diketahui bahwa data hasil belajar siswa terdistribusi normal dan homogen maka dapat dilakukan uji hipotesis dengan menggunakan uji statistik uji $\mathrm{t}$ dua pihak. Uji ini untuk mengetahui apakah hipotesis dalam penelitian ini diterima atau ditolak. Kriteria 
pengujian jika $t_{\text {hitung }}>t_{\text {tabel }}$ maka hipotesis alternatif diterima dan hipotesis nihil atau hipotesis nol ditolak. Data hasil uji hipotesis dapat dilihat pada Tabel 4. Dari data distribusi $\mathrm{t}$ diperoleh $\mathrm{t}_{\text {tabel }}=1,994$. sedangkan berdasarkan perhitungan diperoleh $\mathrm{t}_{\text {hitung }}=$ 2,80 sehingga harga $t_{\text {hitung }}>t_{\text {tabel }}(2,80$ $>1,994)$. Dengan demikian Ho ditolak, Ha diterima. Berarti: Ada perbedaan hasil belajar siswa yang diajarkan menggunakan model make a match dengan hasil belajarkimia siswa yang diajarkan menggunakan model teams games tournamentdengan bantuanpowerpoint padapokok bahasan koloid.

\section{Rata-Rata Nilai Gain}

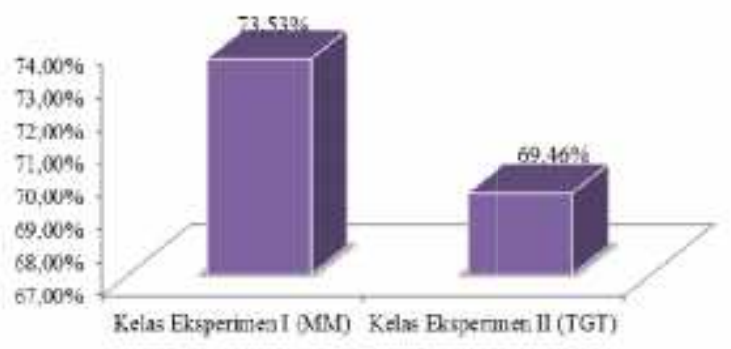

Gambar 2.Diagram rata-rata nilai gain

\section{KESIMPULAN}

Penelitian ini menunjukkan bahwa peningkatan hasil belajar dengan model Make a Match dengan media PowerPoint lebih tinggi yakni sebesar $73,53 \%$ dengan kualifikasi gain tinggi daripada peningkatan hasil belajar di kelas eksperimen II yang menerapkan model Teams Games Tournament dengan media PowerPoint, yakni sebesar 69,49\% dengan kualifikasi gain sedang. Faktor-faktor yang mempengaruhi hal tersebut antara lain adalah: (1) Model make a match (membuat pasangan) merupakan salah satu jenis dari model dalam pembelajaran kooperatif. Salah satu keunggulan teknik ini adalah siswa mencari pasangan kartu dalam belajar mengenai suatu konsep atau topik, dalam suasana yang menyenangkan. Model pembelajaran make a match baik digunakan manakala guru menginginkan kreativitas berfikir siswa, sebab melalui pembelajaran seperti ini siswa terlibat langsung dalam menjawab soal yang disampaikan kepadanya melalui kartu dan pembelajaran lebih menyenangkan karena melibatkan media pembelajaran yang digunakan guru yaitu kartu pembelajaran,

PowerPointmerupakan suatu media yang digunakan dalam kegiatan pembelajaran, sehingga pembelajaran dapat lebih intraktif dan dapat memberikan pengalaman visual kepada siswa dalam rangka memberi motivasi belajar, memperjelas, dan mempermudah konsep yang kompleks serta abstrak menjadi lebih sederhana, konkrit, juga mudah dipahami.

Ada perbedaan hasil belajar siswa sebesar $4,07 \%$ dikedua kelas yang menggunakan model yang berbeda yaitu model pembelajaran make a match di kelas eksperimen I dan model teams games tournament di kelas eksperimen II dengan bantuan powerpoint pada pokok bahasan koloid.

\section{Ucapan Terimakasih}

Penulis mengucapkan terimakasih kepada kedua orang tua. Terima kasih juga penulis sampaikan kepada Ibu Lisnawaty Simatupang,S.Si.,M.Si sebagai dosen pembimbing. Serta terima kasih untuk Kepala sekolah SMA N 1 Binjai Bapak Susianto,S.Pd,M.Si, dan Ibu Dra. Lorista Pane, S.Pd selaku guru kimia SMA N 1 Binjai, serta siswa-siswi SMA N 1 Binjai khususnya kelas XI IPA 2 dan XI IPA 3.

\section{DAFTAR PUSTAKA}

Chonstantia.A.L. (2013). Penerapan model pembelajaran make a match dan diskus kelompok untk meningkatkan motivasi berprestasi, rasa ingin tahu dan prestasi belajar pada materi hidrokarbon di kelas $\mathrm{x}$ SMAN 2 Boyolali tahun ajaran 2011/2012.Jurnal Pendidikan Kimia, 2(3) Tahun 2013.

Dahria, M dan Ismawardi, S. (2009).Manfaat PowerPoint Dalam Presentasi Makalah, Jurnal Saintikom Vol 6 No 1 Tahun 2009.

Dash, J. (2014).Penerapan Model Pembelajaran Kooperatif Tipe TGT 
(Teams Games Tournament) Dengan Media Microsoft Office PowerPoint Untuk Meningkatkan Hasil Belajar Siswa Pada Pokok Bahasan Hidrolisis Garam., Skripsi, FMIPA, Unimed, Medan.

Dora. (2013).Peningkatan Hasil Belajar Siswa Menggunakan Media Kartu Positif dan Kartu Negatif Pada Pembelajaran Matematika, Artikel Penelitian, PGSD Universitas TanjungPura Pontianak.

Ekawati, E. (2013). Efektivitas Metode Pembelajaran Teams Games Tournament Yang Dilengkapin Dengan Media PowerPoint Dan Destinasi Terhadap Prestasi Belajar, Jurnal Pendidikan Kimia Vol 2 No 1 Tahun 2013.

Fadliana, H. N. (2013). Studi Komparasi Penggunaan Metode PBL Dilengkapin Dengan Macromedia Flash Dan LKS Terhadap Prestasi Belajar Ditinjau Dari Motivasi Belajar Siswa SMP Negeri 1 Jaten Karanganyer Tahun Pelajaran 2012/2013, Jurnal Pendidikan Kimia Vol 2 No.3 Tahun 2013.

Hamalik, O. (2008).Kurikulum dan Pembelajaran, Bumi Aksara, Jakarta

Istarani., (2012), 58 model pembelajaran inovatif, Media Persada, Medan.

Justiana, S.,dan Muchtaridi. (2007).Kimia SMA/MA Kelas XI, Yudhistira, Jakarta.

Mentari, M.U. (2014).Studi Perbandingan Hasil Belajar Kimia Siswa Menggunakan Model Pembelajaran PBL (Problem Based Learning) dan Model Pembelajaran TPS (Think Pare Share).,Skripsi, FMIPA, Universitas Bengkulu, Bengkulu.

Mufidah, L. (2014).Penerapan Model Pembelajaran Kooperatif Tipe TPS untuk Meningkatkan Aktivitas Belajar Siswa pada Pokok Bahasan Matriks, Jurnal Pendidikan Matematika STKIP PGRI Sidoarjo Vol 1 No 1 Tahun 2013.

Mursid. (2013).Pengembangan Model Pembelajaran Berbasis Kompetensi Suatu Pendekatan Pembelajaran Praktik Berbasis Kompetensi Berorientasi Produk pada Pendidikan Teknik Mesin, UNIMED PRESS, Medan
Ngalimun.(2014).Strategi dan Model Pembelajaran, Aswaja Pressindo,Banjarmasin.

Nurseto, T., (2011), Membuat Media Pembelajaran yang Menarik, Jurnal Ekonomi dan Pendidikan8: 20-22.

Nopiyanti, T. (2013). Penerapan Model Pembelajara Kooperatif Tipe Teams Games Tournament Untuk Meningkatan Prestasi Belajar Kimia Dan Kreativitas Siswa Pada Materi Reaksi Redoks Kelas X SMA N 3 Sukaharjo Tahun Pelajaran 2012/2013, Jurnal Pendidikan Kimia Vol 2 No 4 Tahun 2013.

Prihantoro, D. (2013) Studi Komparasi Pembelajaran Make a Match Dan Teams Games Tournament Menggunakan Media Scramble Game Pada Materi Pokok Koloid Kelas XI SMA Negeri 1 Surakarta Tahun Pelajaran 2012/2013, Jurnal Pendidikan Kimia Vol 3 No 3 Tahun 2014 Purba, M., (2007), Kimia untuk SMA Kelas XI Semester 2, Erlangga, Jakarta.

Putri, I.P. (2013). Penerapan Metode Pembelajaran TGT Dilengkapin Kartu Destinasi Untuk Meningkatkan Minat Dan Prestasi Belajar Pada Materi Minyak Bumi Kelas X SMA Negeri GindangRejo Tahun Pelajaran 2012/2013, Jurnal Pendidikan Kimia Vol 2 No 4 Tahun 2013.

Rusman.(2011).Model-Model Pembelajaran Mengembangkan Profesionalisme Guru. Rajagrafindo Persada, Jakarta.

Sanjaya, W. (2012).Media Komunikasi Pembelajaran, Kencana Prenada Media Group, Jakarta.

Silitonga, P. M. (2011).Metodologi Penelitian Pendidikan, FMIPA Universitas Negeri Medan, Medan.

Silitonga, P. M. (2011).Statistik Teori dan Aplikasi Dalam Penelitian, FMIPA Universitas Negeri Medan, Medan.

Sudarmo, U. (2013).Kimia untuk SMA/MA Kelas XI Kurikulum 2013, Erlangga, Jakarta.

Sugiharti, G.(2013).Evaluasi dan Penilaian Hasil Belajar Kimia, Universitas Negeri Medan, Medan. 
Suparno.(2012).Dinamika Partikel Koloid, UNY Press, Yogyakarta

Syadiyah, H. (2013).Kacaunya Pendidikan Di Indonesia, Artikel, FIP Universitas Negeri Semarang

Tanjung, F. (2013).Strategi Belajar Mengajar, UNIMED PRESS, Medan

Trianto. (2011).Mendesain Model Pembelajaran Inovatif Progresif: Konsep, Landasan dan Implementasinya Pada Kurikulum Tingkat Satuan Pendidikan (KTSP), Kencana Perdana Media Group, Jakarta. 